\title{
BUSINESS MODEL INNOVATION AS A TOOL TO ESTABLISH CORPORATE SUSTAINABILITY
}

\section{Csaba Fogarassy ${ }^{1 *}$, Balint Horvath', Robert Magda ${ }^{2}$}

\author{
'Climate Change Economics Research Centre, Faculty of Economics and Social Sciences, Szent István University, Gödöllö, Hungary \\ 2Institute of Economics, Law and Methodology, Faculty of Economics and Social Sciences, Szent István University, Gödöllő, Hungary
}

Considering the frequently changing business environment, staying competitive on the current markets takes more efforts from companies in the $21^{\text {st }}$ century. Conducting only incremental product innovation does not meet the market criteria anymore. The successful entrepreneurs of the future must focus more on the design of their business models to gain superior economic performance. Besides the market, society has also raised a major requirement towards companies, which is being socially responsible. The word 'sustainability' regarding businesses might confuse a lot of people as several aspects of the term reach beyond its traditional economic interpretation. The present study provides a clear explanation and furthermore examines its application at a corporate level. This paper aims to present how business model innovation does not simply lead to economic success but its generated value can be extended to social and environmental aspects as well.

Keywords: business model innovation; business models for sustainability; corporate sustainability; corporate social responsibility; sustainability management

\section{Introduction}

Whenever people are asked about the longest lifespan in the history of business, they mostly reply with cautious assumptions of around 50 or 60 years. The courageous ones might go a bit above 100 years with their estimations but the truth is that $95 \%$ are far from the right answer. The longest running company in history lasted for over 1400 years. The origins of the Japanese construction company called Kongo Gumi can be traced back to 578 A.D. and it was absorbed in 2006 by another Japanese firm as a subsidiary. In defence of the people who might underestimate this number, the truth is that a long corporate lifecycle is not a daily occurrence nowadays. After appearing on Fortune magazine's famous 'Fortune 500' list in 1970, a third of those once highly successful companies were out of business by the year of 1983. This fact goes back more than 30 years in time and the circumstances of operating businesses have not gotten any easier. After entering the $21^{\text {st }}$ century, we have come to the world of digitalization which is quite an inconvenient environment for the ones showing resistance to change. The processes of the business world became faster. The phenomenon of start-ups turning into 'tech-unicorns' ${ }^{11}$ one day and running out of business the other, has become a daily experience.

The ever-changing nature of business has indicated new forms of processes at companies. Most of all, innovation has started to play a bigger role in staying competitive on the market. But for now, the face of innovation or at least its application - has changed. Decades ago it was enough for companies to rely on simple product development or incremental innovation 2 . According to the recent trends, this form of innovation itself does not stand the market criteria anymore (Amit and Zott, 2010). One of the most well-known examples for this outdated procedure is Sony's Walkman. The product which now seems to be a technology from Stone Age was once a brilliant invention. The portable cassette/tape player allowed people to carry music with them in a comfortable way. Still, Sony has stuck with technological improvements

1 Tech-unicorn: companies that were start-ups in the near past and currently valued over 1 billion USD

2 Incremental innovation: the continuous improvement of an already existing product or product line to maintain or enhance its competitiveness. for many years, even when they needed to react to digitalization. First, they came up with the Discman, and then they started to produce Mp3 players to stay competitive on the 'Portable Media Player market'. However, after 2004 it was another product to gain a remarkable share of the U.S. market, called iPod. The revolutionary invention of Apple was neither the first device to play digital music, nor the first on the field of downloading music. It was their combination and the business model built around these functions which attracted a wide range of consumers (Amit and Zott, 2012).

Even though most of the current businesses fail to locate their relevant target groups, a more significant problem is the misinterpretation of the real market needs. The so-called 'pain-and-gain' relation has been one of the most interesting research fields for marketing experts since the 1950's. It means a special problem or need (pain) of the customers which needs to be solved or satisfied with a product or a service (gain). But once we develop a misconception about the problem, the solution is never going to reach its target (0sterwalder and Pigneur, 2010). For a better explanation, we can use the practical example of iPod again. In this case, Apple started with understanding the real pains of the people and the reason why they downloaded music instead of buying it. It was genius in the first place because the latter aspect was not even their concern; it rather belonged to the music industry. Eventually, they have found that people do not pirate music from the internet due to financial reasons but because they are tired of buying complete albums for one or two hits. Since the quality of the illegal music was not perfect anyway, customers were willing to pay for music but only if they could choose their most desired tracks and buy them individually. Apple, as a company with a portable media player discovered a need which fell out of their industry and decided to utilize it for its own. Besides the hardware, they developed the software iTunes as well and made contracts with stakeholders from the music industry to distribute their songs. Ever since that time, iPod has been considered as one of the most successful business models of our times.

After the short case study of Apple, interpreting the role of innovation at a company would be easier. The example of Sony showed a stubborn and narrow-minded approach towards the changing business environment. In other words, they could not give up on their product and its development 
while it has been outdated for a long time. In the contrary, Apple took the effort of asking their customers before they even tried to sell anything to them. Furthermore, they did not focus on the product as much as on the mechanism they built around it. This way, they could create a clear value in parallel with actual customer needs and made sure this value would be delivered to their target group. By the current scientific language, this activity is referred as business model innovation (Chesbrough, 2010). Since the end of the $21^{\text {st }}$ century the elaboration on business models is one of the most emerging topics in academic business studies.

Another well-researched area in the field of business focuses on how companies can contribute to social good or act in an environmentally conscious way. These aspects fall under the scope of the term 'Corporate Social Responsibility' (CSR) (Lindgreen and Swaen, 2010). Both perspectives have attracted major notice since the traditional capitalist perception of companies seemed to fail them lately. In the case of society, it has become clear that the regular profit-maximizing model considers people as simple production factors instead of human beings. Concerning the environment, the same forprofit mentality has brought humanity to the edge of significant biodiversity losses which cannot be reversed (Storm, 2009). Poverty, hunger, social disparities, climate change, the distinction of species, water and soil pollution are the most relevant challenges of our times. Despite the denial of some of these phenomena, they are real and their source lies in our current economic systems. Therefore, society has already expressed its need towards the private sector to take into consideration the social and environmental aspects and to act responsibly regarding these matters.

Unfortunately, the interpretation of CSR principles has been carried out in the same manner which has always been performed by profit-oriented companies. Instead of taking actions with real impact, firms started to use CSR for marketing purposes. Apparently, they truly invested in social or environmental projects to prove themselves socially or environmentally responsible. However, their initiatives turned to be fruitless in order to gain major results (Cai et al., 2012). A good example is Coca-Cola which would support sport tournaments in any way to promote the brand. But to fulfil the CSR criteria they claim that their real motive is making healthy lifestyle more popular. Or companies buy a single hybrid or electric car to extend their car fleets and state that their transportation is more sustainable by that. To label this attitude, the scientific language uses the term 'Greenwashing', which stands for the deceptive marketing behaviour of companies to appear environmentally friendly (Delmas and Burbano, 2011).

After the saddening example of misleading CSR practices, the positive endeavours should be mentioned as well. As a matter of fact, there are certain initiatives with the real aim of achieving social or environmental impacts. Mostly, they come from two major sources: socially engaged organizations within the public sector or from the government itself. Their only problem is their public recognition which admits their benefits, but at the same time considers them financially inefficient. It comes from the regular perception in the world of business which assumes a trade-off between economic and social/environmental values (Wagner, 2007). According to personal interview results, in some cases even the owners of impact projects consider their activity as charity which is affordable for them besides their flourishing forprofit businesses. This is where the real problem lies. Based on the previous practice, social and environmental initiatives have been carried out by serious financial contributions from governmental or other sources. However, after the funding period they could not prove themselves viable on commercial basis. The reason is the nature of their benefits which cannot be monetized. The impact of social or environmental projects can hardly be expressed in the form of any currencies (Fogarassy and Böröcz, 2014). Even though at some cases the results can be quantified, the market cannot react on them if they do not have a price tag.

This is where the application of business model innovation comes in. Until now, this article mainly examined two aspects of the business world. One is the ever-changing business environment which cannot be answered by simple incremental innovation in the $21^{\text {st }}$ century. The entrepreneurs of this time must think in new mechanisms to make their businesses work (Illés et al., 2015). The other relevant topic of this paper focuses on the challenges of business sustainability. Recent theoretical and practical researches showed that these two perspectives cannot only be combined but they can answer each other's weaknesses (Pauli, 2010). On one hand, the financial state of an impact activity can be secured by appropriate business models. 0 n the other, business models which are designed in accordance with natural ecosystems would be able to surpass 'business-as-usual' solutions. In the next chapter of this article the authors tend to provide a deeper insight regarding business model innovation and its relevance at a corporate level. Furthermore, the paper will elaborate on sustainability principles and the way they can be applied through the design of business models.

\section{Understanding the concept of business models Thinking outside the box}

The importance of business models emerged in the late $20^{\text {th }}$ century. Until that point the attention of firms focused strictly on their products. After their markets have become fully covered by similar competing products, corporate leaders have been forced to change their perceptions. The structure of businesses and the exploration of new channels to reach customers have turned to be more important than the product itself. One of the most popular concepts concerning the relevance of business models is called 'Blue Ocean Strategy'.

It defines old-fashioned companies as market players in 'red oceans'. The colour stands for the so-called 'bloody competition' in order to gain bigger share on a market which is already filled with many competitors. The ones labelled with the colour of 'blue' are innovative businesses aiming to discover new markets (Kim and Mauborgne, 2004). The major differences of these two approaches are highlighted in Figure 1.

The table clearly illustrates the new level of thinking on which the Blue Strategy operates. The most popular example to demonstrate these differences is the story of the French circus called 'Cirque du Soleil'. Their business was

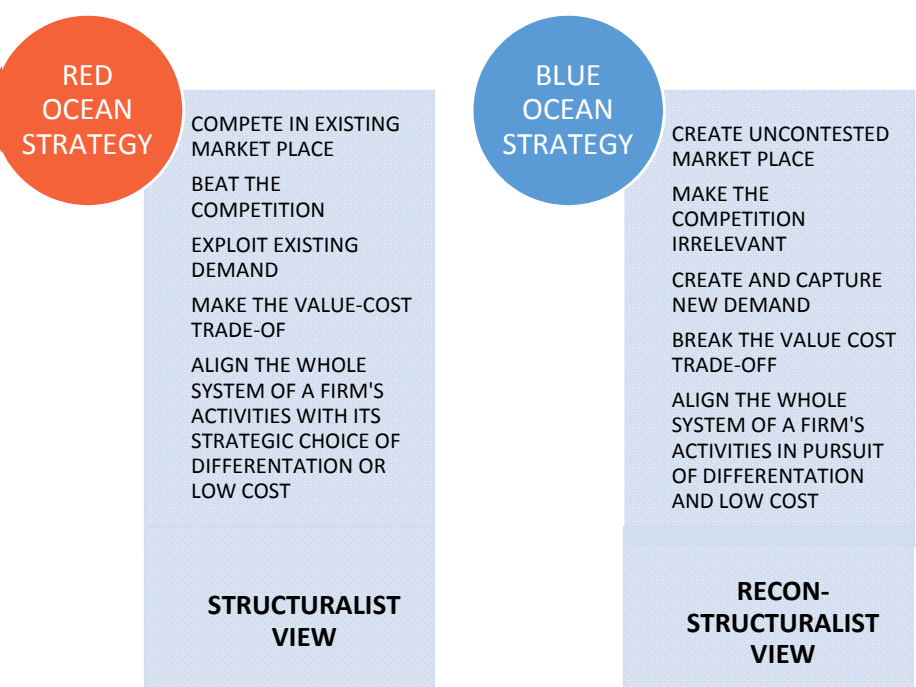

Figure 1 The differences between the Red and the Blue 0cean Strategy Source: based on Kim and Mauborgne, 2005 
founded in the mid-1980s, an inconvenient time for circuses. They lost their target group - the children - to new computer games and animal right activists gained more power protesting against animal use in circus stunts. While other circuses have been experimenting with old methods - like hiring famous clowns which only increased their costs - the heads of Cirque du Soleil reinvented the world of entertainment. Since the animals stood for most of the maintenance costs and caused legal problems anyway, this circus eliminated them from its shows. They used the same approach in the case of clowns. If they cannot bring customers under the tent anymore, their role must be decreased as well. With these moves the circus ruled out two segments from their operation which would have cost a lot without gaining any benefits for them. It was a brand new, innovative perception of entertainment, because until this point nobody would have imagined a circus without clowns or animals. However, this was only the beginning.

The leaders of the company admitted that in case of a circus the basic value proposed is a leisure activity. Therefore, they do not only compete with other circuses but also with other alternatives offering the same nature of service, such as restaurants, cinemas or theatres. After realizing the decreasing interest of children in circus stunts, the Cirque du Soleil started to focus on adults. They excluded the ridiculous and non-coherent acts and decided to provide their customers with a complete story. For a more interesting, dramaturgic plot they copied the

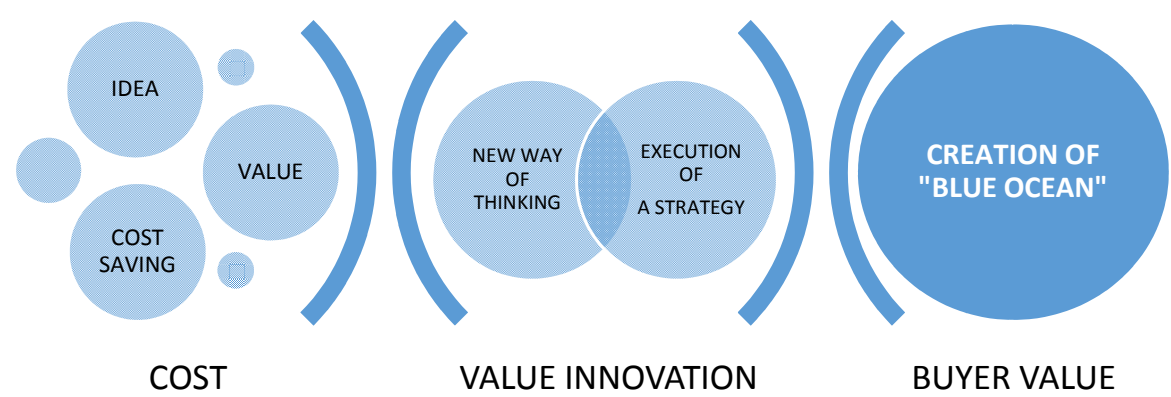

Figure 2 The definition and visualization of Value Innovation Source: based on Kim and Mauborgne, 2005

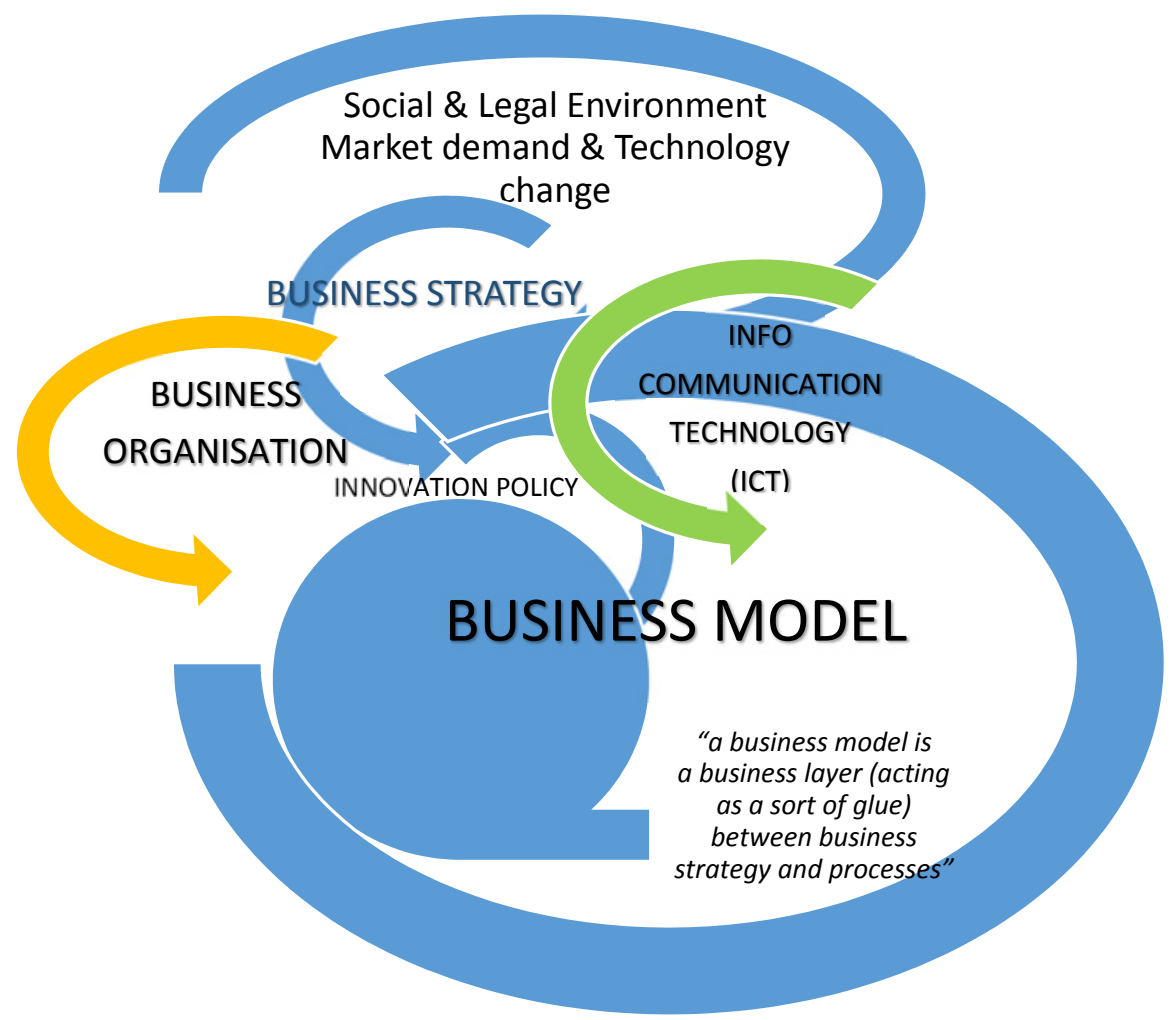

Figure 3 Environment, Business Model, Strategy, Process and Information Systems Source: based on 0sterwalder, 2004

storylines of Russian theatres. In the place of clowns and animals they employed more acrobats to achieve a spectacular visual impact. After all these amendments, the value proposition of the Cirque du Soleil was a sophisticated experience targeting a whole new customer group. The case of this French circus stands as a good example for thinking outside an established conceptional framework and creating new markets instead of competing on existing ones. They did not have to consider other circuses during the expansion of their market share because they did not have to share the market with anyone else.

In a certain way, the story of the Cirque du Soleil is quite similar to Apple's which was presented earlier in this paper. Neither their product, nor their service was first of their kind; still, the value they offered to people had no competitors. That might be the way how incremental and business model innovation can be differentiated from each other. While in the first aspect the product or the service receives major attention, the latter focuses on the development of an outcome rather referred as 'value'. Figure 2 presents the Value Innovation process according to the concept of Blue Ocean Strategy.

For a detailed elaboration on the figure, the example of the Cirque du Soleil can be recalled again. They achieved cost savings through eliminating animal stunts and reducing clown acts from their show. Furthermore, by creating a whole new entertainment function with sophisticated storylines and the involvement of more acrobats, their buyer value has been increased as well. These two factors allowed them to come across the borders of their previous market and left them without any competitors in their blue ocean.

\section{What is a business model?}

The previous sub-section declared the importance of focusing on business structures instead of simple product development procedures. The conclusion that can be drawn from it is that businesses in the $21^{\text {st }}$ century do not offer products or services anymore. They deliver values. To comprehend the mechanism behind this process, we must first understand what a business model is at all. Despite the history of this concept, numerous interpretations emerged for its definition in the last few decades. The idea of a business model is like a poem, there will never be two different people with the same articulation of it. The ones trying to communicate its theoretical meaning often fall into the same trap as its practical users. Most of young entrepreneurs fail to elaborate on their businesses in a short, clear 
and comprehensive way. This is what happens in the field of theory, when a definition on business models turns to be long and far more detailed as it is supposed to be. Alexander Osterwalder, the pioneer of modern business model researches conducted an extensive research on business

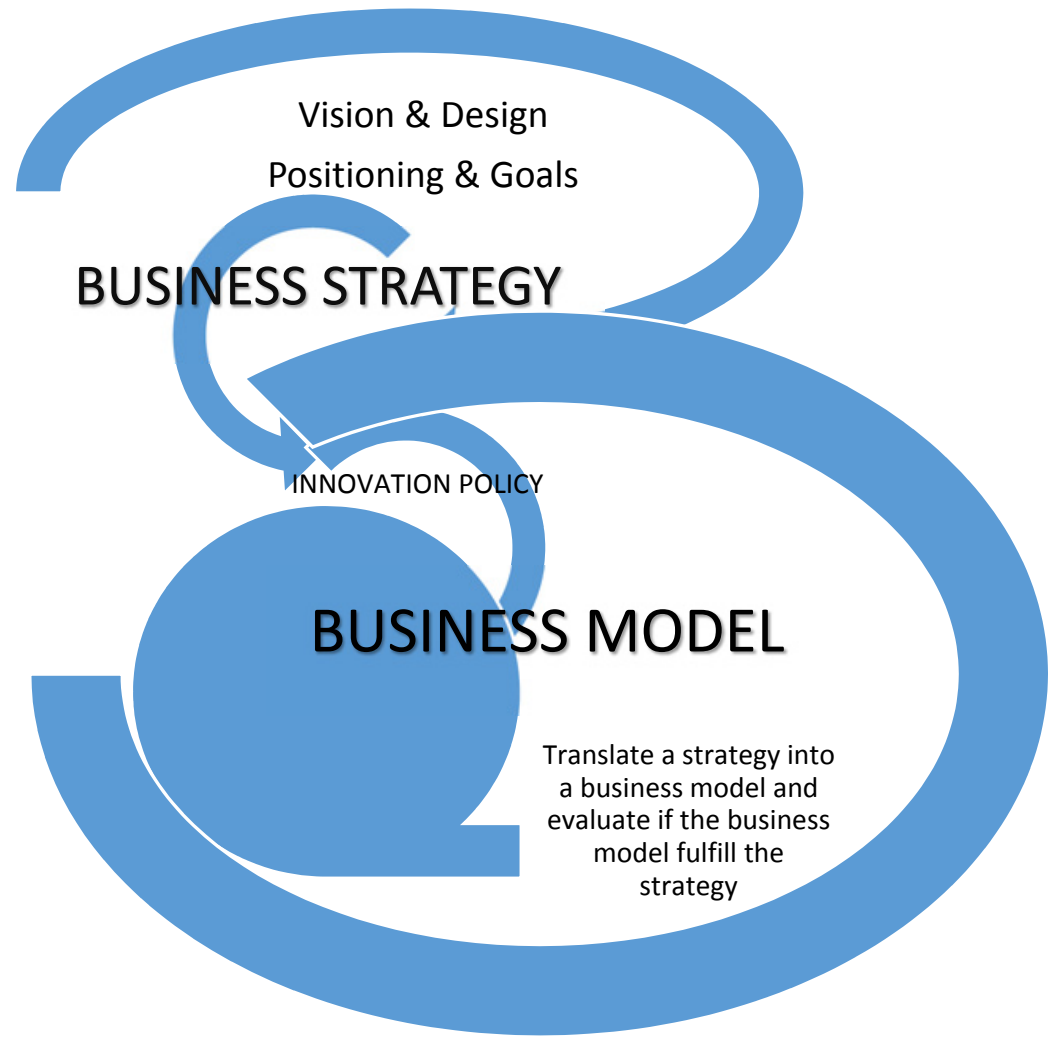

Figure 4 The connection between Business Strategy and Business Model Source: based on 0sterwalder, 2004

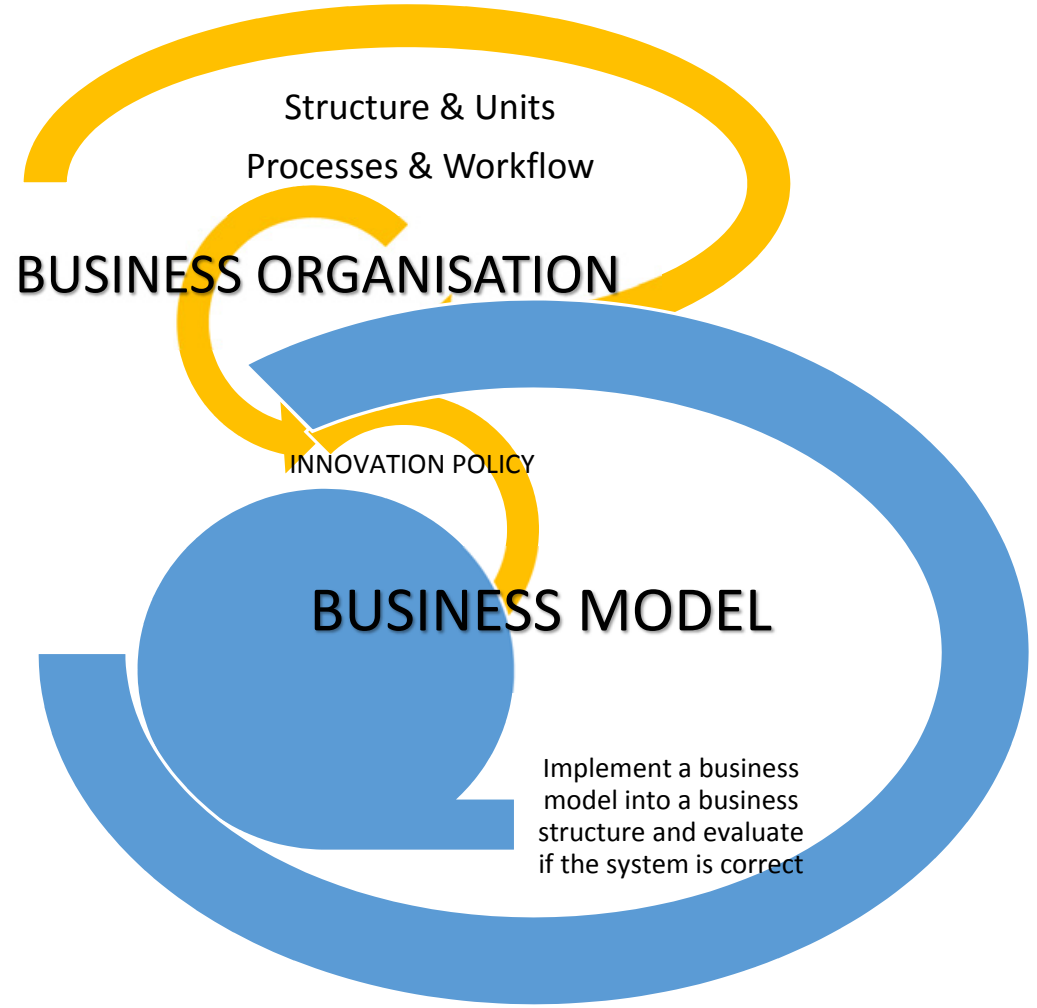

Figure 5 The connection between Business Organization and Business Model Source: based on 0sterwalder, 2004

model ontology and summarized its essence in one short sentence: "an abstract conceptual model that represents the business and money earning logic of a company" (Osterwalder, 2004).

Even though the essential substance of the concept is well described in these few words, its function leaves more room for interpretation. Following the logic of Osterwalder, the business model shows the way towards the goals, set by the business strategy. In other context, the business model ties together the business strategy with other elements of the business and with its environment (Figure 3). As Osterwalder phrases it: "a business model is a business layer (acting as a sort of glue) between business strategy and processes" (Osterwalder, 2004).

The figure illustrates how a business model stands in the middle of a business as a link between its internal processes. Still, it recognizes other, external forces which highly influence the function of a business. Their significant attribute is their continuously changing existence which cannot be reacted simply by the adjustment of internal elements. It is the management's responsibility to alter its business model in order to respond to changes in the environment.

\section{The influence of business models on the internal business elements}

After the global picture, let's see how business models are connected to several elements of a company. Concerning the 'business strategy', the accurate interpretation of the term comes first again. Although there is no approach which would doubt strategy as the most dominant part of a company, its understanding differs by certain schools. In his theoretical overview, Osterwalder collected the most significant characteristics of the business strategy. His summary states that a strategy first sets a company vision and designs the business based on the consideration of internal and external processes (Learned, et al., 1965). Furthermore, it identifies the company's desired market position (Porter, 1985), appoints its goals and objectives, and most importantly determines the accurate way to measure them (Drucker, 1954; Kaplan and Norton, 1992).

Figure 4 clearly describes how a business strategy determines the design of the business model, while the model itself enables (or in bad case prevents) the strategy to fulfil its goals. The easiest way to explain their symbiotic relationship goes through the definition of the questions they provide the answer for. The business strategy always aims to indicate answer for the question 'what?' (or 'which?'). For instance, "what products to sell to which customers?", or "which 
position would be the most suitable considering competitors". Whilst a business model reacts to the question 'how?'; like "how to distribute my products?", or "how to conduct transactions"? The line of the possible questions could go on for long but the core and aim remain the same.

The connection between a business organization and a business model (Figure 5) highlights an important feature mentioned already during the case studies: the structural changes of a company in accordance with the changes in the business environment. Meanwhile the strategy represented the concept behind the company's function, the organization includes the material assets and elements. It consists of the existing department, units and the applied processes and workflow.

Apple's iPod provides a good example to explain the relation of business models to business organizations. That case study stands for several aspects, featuring the ever-changing business environment. One of them is the adaptation to digitalization. Even though previously this term was only used for the digital form of music and the way how Apple reacted on it, there is an alternative interpretation of it as well. In another context, it also means the way how businesses rely more on digital solutions and choose internet as their distribution network (Fleisch et al.,
2015). A phenomenon like that requires major structural changes from a company (e. g. opening new departments, alteration in processes or workflows). Apple provided a best practice case through iTunes of how a company can adjust its business model to digital distribution platforms. However, others were not as successful with similar endeavours. The computer manufacturing company Compaq also intended to react on this trend in the 1990s by introducing online distribution channels to the market. In their case the effort turned to be a disaster as their resellers discovered this new activity and accused them of generating competition. This example shows the way how the misalignment of a business model and a business organization could lead to major concerns.

Showing the increasing importance of digitalization is useful to create a bridge towards the elaboration on the relation between ICT and business models (Figure 6). Meanwhile, it is inevitable to mention a current trend in business which redefines the meaning of digitalization. Whilst the term initially implied to the phenomenon of distributing goods (or even services) online, lately the importance of a company's technological assets has proved to be significant. By the example of such initiatives as Amazon.com or eBay, online companies have

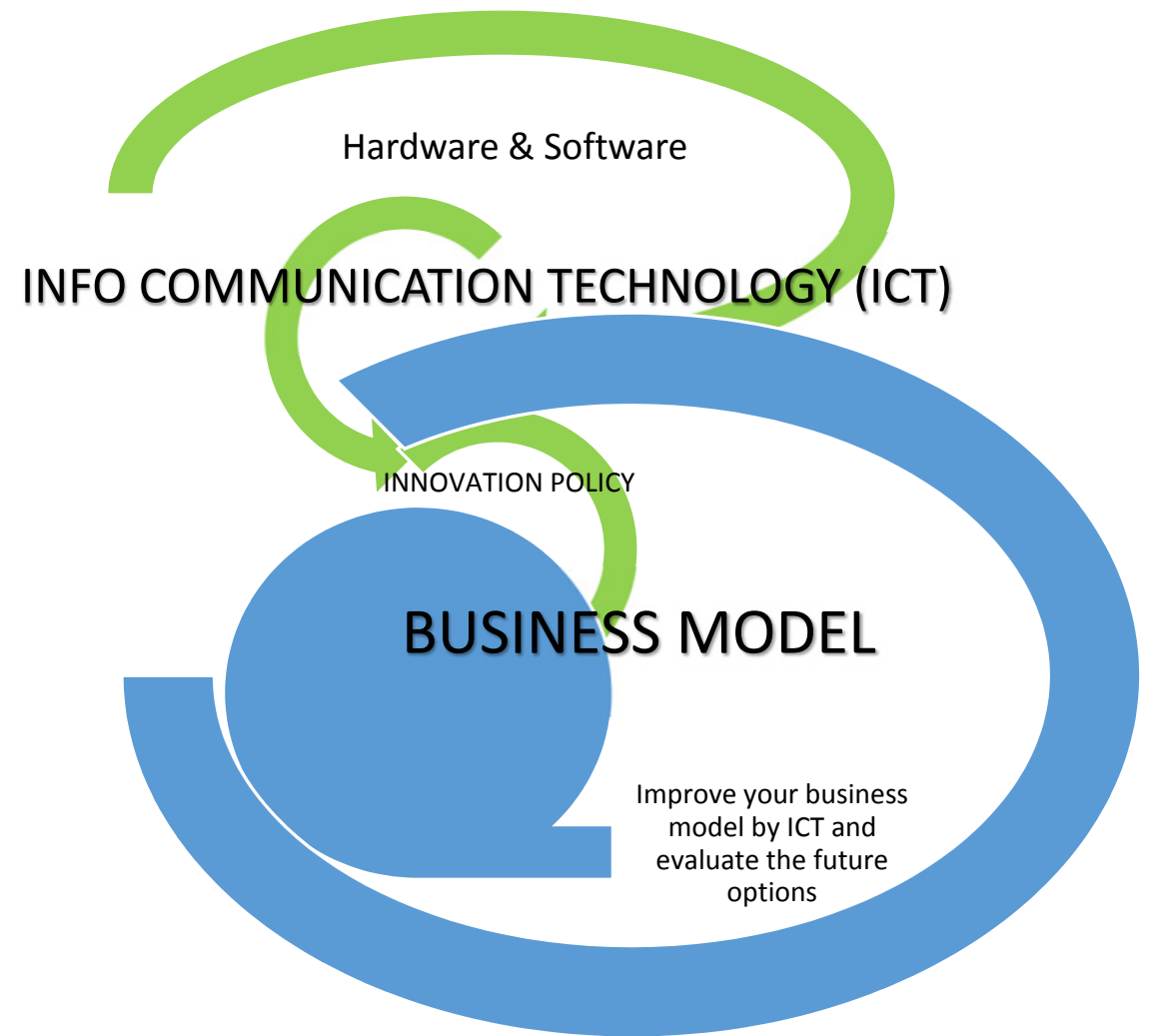

Figure 6 The connection between Business Organization and Business Model Source: based on 0sterwalder, 2004

become parts of everyday lives. Based on the rapidly decreasing ICT costs, business models intensely aim to involve technological features in order to improve their functions and make processes smoother.

Nothing demonstrates the acceleration of change better than observing how Amazon or eBay already represent a big obsolete value proposition. The reason is that digitalization in business already points toward an altered interpretation, the so-called 'uberization' of business models. The company Uber and its wellknown application is currently the favourite case study of many researchers working in the field of business model innovation. The value offered by Uber goes beyond the simple for-profit mentality of businesses and contributes to a greater concept referred as 'Sharing economy's. Since Uber was first identified as the flagship of the new economic perception, the trend has been labelled as the 'uberization' of business models (Davis, 2016). Even though the basic idea has been misinterpreted in many practical applications, the core notion seems to spread around the world. Additionally, the increasing popularity of sharing economy is not as surprising as it might sound for the first time. The shared access system enables a large part of society to get a hold on products or services which they would not be able to afford normally. Furthermore, it strengthens local communities and indicates more sustainable consumer behaviour. Sharing economy contributes to raising social awareness towards the dysfunctions of consumer society (Belk, 2014). By the end of the $20^{\text {st }}$ century, people have become so obsessed with focusing on the ownership of certain products or services; meanwhile they forgot how much these cumulated stocks cost them or the environment. The sharing of these goods saves a lot of expenses for the society and prevents the environmental impact generated by manufacturing them.

At the end of this sub-section the study has already come to the point concerning its main research area: the way business models can contribute to social and environmental sustainability besides their economic efficiency. Still, for the utter understanding of business

3 Sharing economy: an extensive economic term covering a wide range of interpretations. Initially it has mostly been used for online peer-to-peer transactions aiming to share access to goods and services. In a broader sense it involves any transactions conducted through online market platforms, even in the form of business to consumer (B2C) actions. 


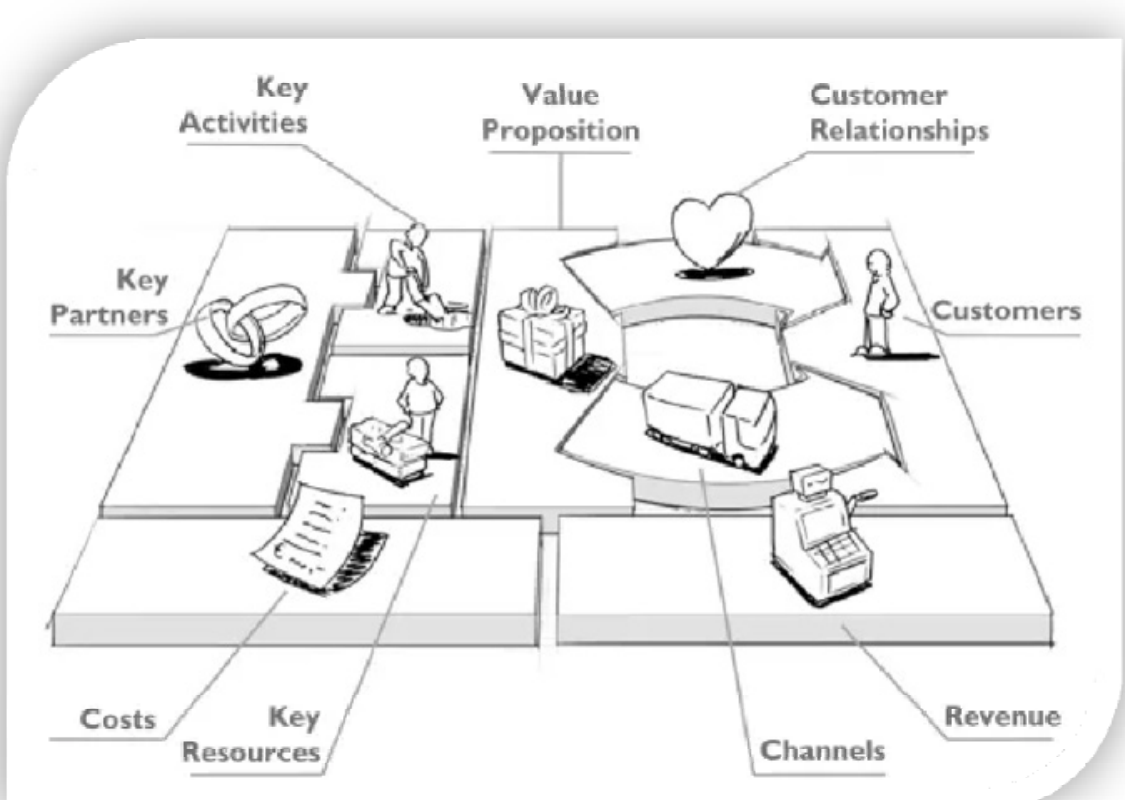

Figure 7 The Business Model Canvas Source: Osterwalder and Pigneur, 2010

models - which is the basic theme of this chapter - their design must be introduced as well.

\section{The design of business models}

The previous sub-sections highlighted the importance of business model innovation, then elaborated on the way business models can

influence the core elements of companies. This sub-section aims to introduce the essential components of a business model and describe how it can be built upon them. For the visualization of these elements, Figure 7 illustrates the widely referred 'Business Model Canvas' (BMC) of Osterwalder and Pigneur (2010).

Table 1 The Four Box Business Model

\begin{tabular}{|c|c|}
\hline Major elements & Sub-elements \\
\hline \multirow[t]{3}{*}{ Customer value proposition } & Target customer \\
\hline & "Job-to-be-done" \\
\hline & Offering \\
\hline \multirow[t]{4}{*}{ Profit formula } & Revenue model \\
\hline & Cost structure \\
\hline & Margin model \\
\hline & Resource velocity \\
\hline \multirow[t]{7}{*}{ Key resources } & People \\
\hline & Technology, products \\
\hline & Equipment \\
\hline & Information \\
\hline & Channels \\
\hline & Partnerships, alliances \\
\hline & Brand \\
\hline \multirow[t]{3}{*}{ Key processes } & Processes \\
\hline & Rules and metrics \\
\hline & Norms \\
\hline
\end{tabular}

Source: Johnson, 2010
Despite many considered factors, all of these segments can be summarized into four simple groups. The first one is located in the middle of the picture which is the value proposed to the customers. Even though it means the heart of the business, it must be defined in accordance with the market needs. This is where the second group, the customer-related elements comes in. At this point, not only the target group and its need should be identified, but also the ways to communicate and deliver our value to them. This part includes the marketing strategy to reach them in the first place, the distribution channels for the product and the definition of client service forms (e. g. call centre). Whenever there is a notion of the first two groups, the company must decide what actions shall be taken for these processes, who they should cooperate with and what resources they need in order to generate the value proposition. These components make the third group on the canvas. The last one involves the balance between the expected costs and revenues. Therefore, it can be identified as the financial model of the business.

As a demonstration of the previously mentioned distinct perceptions of business models and their functions, Table 1 presents a different perspective of component distribution.

The 'Four Box Business Model' is another famous, yet not as widely applied business planning tool compared to the Business Model Canvas. Based on the determined sub-elements, it is obvious that it uses the same set of elements. Still, their classifications slightly differ from each other.

The initial logic of the two models is the same because the first steps include the formulation of the proposed value in accordance with customer needs. Then the Four Box Model already focuses on the financial matters to examine the economic viability in the beginning. In case of the BMC, the customer relations and the business structure are built around the core value and the financial planning came afterwards. Whilst the Four Box Model creates different groups for key processes and key resources, the latter aspect involves attributes (e. g. partners and channels) that were customer related patterns in the BMC. Eventually despite the subtle deviations between the two methodologies, both describe their model as an interaction of the involved elements. It means that one might prioritize certain functions over others, but argues that all must be considered before launching a business.

Although earlier this paper adduced to a quite short and narrow definition of business models, summarizing their structure requires 
a bit more detailed description. Based on the principle of emphasizing the essential substance with being concise in the same way, the definition of Teece (2010) could be the most useful. He states that "A business model describes the design or architecture of the value creation, delivery and capture mechanism employed. The essence of a business model is that it crystallizes customer needs and ability to pay, defines the manner by which the business enterprise responds to and delivers value to customers, entices customers to pay for value, and converts those payments to profit through the proper design and operation of the various elements of the value chain."

After the elaboration on the mechanism of business models, the time has finally come to present how their design can contribute to social and environmental sustainability.

\section{Business models designed for sustainability}

As the brief historical review of the business model theory showed the novel form of this research area, the consideration of environmental and social patterns in business planning appears to be an even younger field of study. The term 'sustainability' has mostly been used before to measure the economic viability of businesses. It has only been a couple of years ago, when researchers started to investigate the potential contribution of business models to sustainable patterns (Schaltegger et al., 2016). To understand the motives of business stakeholders for establishing socially responsible companies, we must first understand their drivers to engage in business model innovation.

\section{Drivers toward business model innovation}

Even though this paper deeply examined the role of business models and the importance of their innovation, there was no intention presented for their application. Johnson et al. (2008) determined five significant factors which would lead existing companies or starting entrepreneurs to business model innovation.

The first one is the discovery of a special need of customers, expressed by a specific social group which cannot access a certain product or service. Their need could be addressed by disruptive innovation, meaning the development of a particular value. The most well-known example for this form is the model of Tata Motors that discovered the hidden demand of the poor Indian society towards new transportation tools. They aimed to react on the pain of customers who could not afford a car but wanted to travel faster on the crowdy roads of India. Therefore, they started to produce Tata Nano whose name refers to its extremely small size and reasonably poor equipment. Their value proposition was a car for the price (and almost the size) of a motorcycle that would be affordable and easy-to-use in the Indian traffic. However, the results of this business seem to fail the initial expectations and there are several reasons for that. The most interesting one is the interest of the targeted people which was far lower than assumed first.

The second pattern is the appearance of new technologies that must be distributed on the market. As a remark from the authors of this paper, this option should be prioritized over the similar previous one. The reason is that the first aspect resembled the old-fashioned practice when the market need was answered by the products a little. It is not surprising that the presented case therefore failed to succeed. Although, at this very field, the technology already exists, the question is "how to enter the market with it?" Concisely, there seems to be more room for business model innovation. A good example for that is the electric car sharing/renting system which has firstly been introduced in Berlin but currently operates in other urban areas as well. In that case, electric cars have been offered for public use, and a fee was charged only for the time of usage. This model resonates with the previous motive as well, since it makes a basically expensive product available for people who would normally not be able to afford it.

The third and the fourth drivers for business model innovation are quite simple as they rely on old market principles. The former is the capitalization of unmet customer needs concerning price or quality matters. The diverse service of FedEx aligned to specific customer needs is a good example for that. For the convenient and smooth service process, FedEx operates at several business segments including worldwide fast-delivery, ground delivery system, provision of less-than-a-truck and ICT support. The fourth motive constitutes the need to defend the market against entering initiatives with innovative products or services. The practice that BMW used in order to compete with Tesla's electric car provides an excellent case to depict this situation.

At last, similarly to the previous pattern, business model innovation is sometimes applied to respond to competition. In this case, the competitor is already on the market and changes are needed to answer their moves. After Hilti recognized its crowded market in the field of selling tools, they started to look for new opportunities within the same business. Soon, they realized that their whole industry faced a major malfunction based on an undiscovered consumer pain. Although their target group, the contractors repeatedly bought their products, after the transaction it meant a burden for them in $90 \%$ of the time. The reason is that construction companies always work on different projects with a specific need of toolset which would only be used occasionally. Still, they must acquire the equipment, even for that short time of usage. That pain has led the leaders of Hilti to implement a whole new perspective focusing on the service instead of the product. They shifted to a new perception saying that "people don't want a drill, they want a whole" and started to lease tools to customers instead of selling it.

During the examination of the main business model innovation drivers, the involvement of social and environmental aspects already emerged at some point. The first two patterns described cases aiming to answer the needs of disadvantaged social groups or finding ways to distribute new technologies among them. Eventually, the case study of Hilti provided a great example for the implementation of the economic concept that prefers services over products. Even if it is far from the idea of sharing economy and its pure purpose was to react on the market competition, it undoubtedly has environmental benefits. Furthermore, sometimes a for-profit based perspective with incremental social or environmental gains can be a solution for planning businesses with valid CSR activity.

This sub-section presented the main motives for business model innovation and unintentionally introduced some cases with actual social and environmental impacts. However, the next part will state the accurate interpretation of corporate sustainability and indicate drivers to engage in it.

\section{Business models for sustainability and motives for implementation}

As it was previously stressed, the aim to achieve social or environmental good in the business sector has always had a controversial discrimination. Before the involvement of such complicated systems like business models, researchers examined the application of simple business cases striving for sustainability. On one hand, social or environmental performance was considered as a sideeffect to the pure economic purpose of a company (Eden, 1994). On the other hand, scholars highlighted 'business cases of sustainability' with the goal to establish corporate sustainability (Dyllick and Hockerts, 2002). In this field, Schaltegger et al. (2012) proposed a third aspect called 'business cases for sustainability'. It was a significant step because this perspective stood for the elimination of the trade-off perception between economic and sustainable values. According to their recognition, a business case for sustainability truly 
realizes positive economic outcome through (and not just along) voluntary social and environmental activities. The same researchers made major contributions to the examination of business model innovation aiming at sustainable patterns.

In this field, the multidimensional interpretation of sustainability appears to be important again. Beyond its economic consideration, some experts focus on its ecological side, while others see business models as tools for addressing social needs. However, both approaches indicate the created value of the company as grounds for defining business models for sustainability. Researchers mostly agree that the organizational value of these models is extended towards social and environmental values. Based on this principle and other relevant literature sources, Schaltegger et al. (2016) identify a business model for sustainability as an instrument which "helps describing, analyzing, managing, and communicating (i) a company's sustainable value proposition to its customers, and all other stakeholders, (ii) how it creates and delivers this value, (iii) and how it captures economic value while maintaining or regenerating natural, social, and economic capital beyond its organizational boundaries." It is obvious that the first two aspects rely on regular business model definitions. They are related to the articulation of the company's value, its creation and its delivery issues. Furthermore, the third point represents the above highlighted perspective, stating that sustainable impacts must align with economic success as well.

After the clear definition on business models for sustainability, the last segment to present in this paper is the elaboration on the main drivers of a company to engage in these business models. As it was highlighted before, the focus on sustainable values may differ at certain researches. Bisgaard et al. (2012) defined motives for 'Green' business model innovation which applies for environmental cases. The first inducement is the representation of entrepreneurial values. This is quite a simple perspective which aims to describe the situation when the entrepreneur is intended to do 'some good' for society or nature. The second motive is to raise consumer awareness. It means the increase of the willingness to pay by offering 'green products' or simply the intention to be recognized as a socially responsible business. The third element is a bit similar to one of the drivers mentioned in case of regular business model innovation. It concerns the maintenance or even the gain of competitive advantages on the market. The application of sustainable tools might not just differentiate a business but also its products or services which therefore seem more appealing to responsible consumers. Another motive can be to reduce costs of resources and supply risks. The most well-known example for this phenomenon is the case of steel industry which dominantly relied on recycled materials for the last 30 years. The reason for that is the major decrease in energy costs by using secondary raw materials. Finally, governmental regulations can also force companies to adapt to sustainable forms of conducting business. Even though a legislation framework is truly important to develop a sustainable business atmosphere (Horvath et al., 2016), the authors of this paper advise policy makers to avoid rigorous measures in order to avoid welfare losses.

As it was clear during their elaboration, these aspects can easily be applied to socially sustainable approaches as well, except for the one striving for cost reduction. Although, the first three drivers may seem naive assuming that consumers are regularly willing to pay more for sustainable labelled products, these incentives are still preferred over simple regulation-based approaches. The latter tool can be dangerous by setting too high standards and decreasing corporate competitiveness.

\section{Conclusions}

The aim of the present paper was to examine the sustainability management issues of a company in the $21^{\text {st }}$ century. This context first required an extended perspective considering corporate challenges of the modern era. The authors initially argued for the importance of business model innovation which has been inevitable for firms lately. The example of the popular business model innovation theory, the Blue 0cean Strategy highlighted the most significant characteristics to stay competitive by literally exiting market competition. In the paper, there were presented the basic features of business models to develop a better understanding on the concept. Certain perspectives emerged for different business model design approaches but their comparison showed similar components behind the distinct perceptions. Another frequently emerging focus point of the research was the application of sustainable principles in corporate function. The consideration of environmental and social values has become a major requirement towards a modern business as well. The literature overview clearly indicated that the extension of a company's value to these aspects is not only applicable, but can lead to higher economic performance in some cases. Finally, the focus of the research was steered towards the main drivers of a company to engage in business models for sustainability. The results demonstrated several motives besides governmental legislation. As a consensus on the topic, the authors state that market-led approaches are more likely to succeed in the field of extended corporate sustainability. There are many economic inducements for companies to commit themselves to sustainable values but forcing them might lead to serious welfare losses.

\section{Acknowledgement}

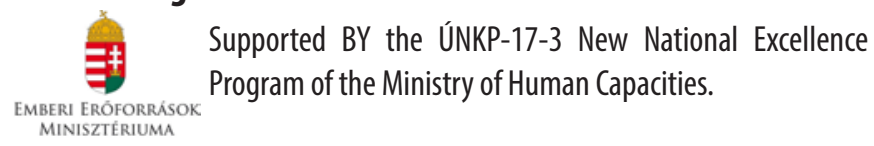

MINISZTÉRIUMA

\section{References}

AMIT, R. - Z0TT, C. 2010. Business Model Innovation: Creating Value in Times of Change, IESE Working Paper, no. WP-870, Barcelona : IESE Business School/University of Navarra, 2010.

AMIT, R. - ZOTT, C. 2012. Creating Value Through Business Model Innovation. In MIT Sloan Management Review, vol. 53, 2012, no. 3, pp. 41-49.

BELK, R. 2014. You are what you can access: Sharing and collaborative consumption online. In Journal of Business Research, vol. 67, 2014, no. 8, pp. 1595-1600. http://dx.doi. org/10.1016/j.jbusres.2013.10.001

CAI, Y. - J0, H. - PAN C. 2012. Doing Well While Doing Bad? CSR in Controversial Industry Sectors. In Journal of Business Ethics, vol. 108, 2012, no. 4, pp. 467-480. http:// dx.doi.org/10.1007/s10551-011-1103-7

CHESBROUGH, H. 2010. Business Model Innovation: Opportunities and Barriers. In Long Range Planning, vol. 43, 2010, no. 2-3, pp. 354-363. http://dx.doi.org/10.1016/j. Irp.2009.07.010

DAVIS, G. F. 2016. Organization Theory and the Dilemmas of a Post-Corporate Economy. in Joel Gehman, Michael Lounsbury, Royston Greenwood (ed.) How Institutions Matter! In Research in the Sociology of Organizations. Emerald Group Publishing Limited, vol. 48B, 2016, pp. 311-322. http://dx.doi.org/10.1108/S0733558X201600048B011

DELMAS, M. A. - BURBAN0, V. C. 2011. The Drivers of Greenwashing. In California Management Review, vol. 54, 2011, no. 1, pp. 64-87. http://dx.doi.org/10.1525/ cmr.2011.54.1.64

DRUCKER, P. 1954. The Practice of Management. HarperCollins Publisher, 1954, pp. 416.

DYLLICK, Y. - HOCKERTS, K. 2002. Beyond the Business Case for Corporate Sustainability. In Business Strategy and the Environment, vol. 11, 2002, no. 2, pp. 130-141. http:// dx.doi.org/10.1002/bse.323 
EDEN, S. 1994. Using sustainable development: The business case. In Global Environmental Change, vol. 4, 1994, no. 2, pp. 160-167.

FLEISCH, E. - WEINBERGER, M. - WORTMANN, F. 2015. Business Models and the Internet of Things. In Interoperability and Open-Source Solutions for the Internet of Things, vol. 9001, 2015, pp. 6-10. http://dx.doi.org/10.1007/978-3-319-16546-2_2

FOGARASSY, CS. - BAKOSNÉ, B. M. 2014. Externality Analysis of Sustainable Cattle Breeding Systems. In Hungarian Agricultural Engineering, vol. 26, 2014, pp. 5-10. http://dx.doi.org/10.17676/HAE.2014.26.5

HORVATH, B. - BOROCZ, M. - ZSARNOCZAI, S. - FOGARASSY, CS. 2016. Long-term green innovation opportunities within the Hungarian district heating sector towards 2030. In YBL Journal of Built Environment, vol. 4, 2016, no. 1, pp. 12-24. http://dx.doi. org/10.1515/jbe-2016-0002

ILLÉS, B. CS. - DUNAY, A. - JELONEK, D. 2015. The entrepreneurship in Poland and in Hungary. Future entrepreneurs education perspective. In Polish Journal of Management Studies, vol. 12, 2015, no. 1, pp. 45-58.

JOHNSON, M. - CHRISTENSEN, C. - KAGERMANN, H. 2008. Reinventing your business model. In Harvard Business Review, vol. 86, 2008, no. 12, pp. 50-59.

JOHNSON, M. 2010. Seizing the white space. Business model innovation for growth and renewal. Harvard : Business Press, 2010, pp. 240.

KAPLAN, R. S. - NORTON, D. P. 1992. The balances scorecard measures that drive performance. In Harvard Business Review, vol. 70, 1992, no. 1, pp. 71-79.

KIM, W. C. - MAUBORGNE, R. 2005. Blue Ocean Strategy: How to Create Uncontested Market Space and Make Competition Irrelevant. Harvard : Business Review Press, 2005, pp. 256.

LEARNED, E. P. - ANDREWS, K. R. - CHRISTENSEN, C. R. - GUTH, W. D. 1965. Business policy: text and cases. Illinois : Iriwn, Homewood, 1965.

LINDGREEN, A. - SWAEN, V. 2010. Corporate Social Responsibility. In International Journal of Management Reviews, vol. 12, 2010, no. 1, pp. 1-7. http://dx.doi.org/10.1111/ j.1468-2370.2009.00277.x

OSTERWALDER, A. 2004. The Business Model Ontology: A proposition in a Design Science Approach : PhD Dissertation, University of Lausanne, 2004, pp. 169.
OSTERWALDER, A. - PIGNEUR, Y. 2010. Business Model Generation: A Handbook for Visionaries, Game Changers, and Challengers. John Wiley and Sons, 2010, pp. 288.

PAULI, G. A. 2010. The Blue Economy: 10 Years, 100 Innovations, 100 Million Jobs. Paradigm Publications, 2010, pp. 336.

PORTER, M. E. 1985. How information gives you competitive advantage. In Harvard Business Review, vol. 63, 1985, no. 4, pp. 149-160.

SCHALTEGGER, S. - LÜDEKE-FREUND, F. - HANSEN, E. 2012. Business cases for sustainability: the role of business model innovation for corporate sustainability. In International Journal of Innovation and Sustainable Development, vol. 6, 2012, no. 2, pp. 95-119. http://dx.doi.org/10.1504/JISD.2012.046944

SCHALTEGGER, S. - HANSEN, E. - LÜDEKE-FREUND, F. 2016. Business Models for Sustainability: Origins, Present Research, and Future Avenues. In Organization \& Environment, vol. 29, 2016, no. 1, pp. 3-10. http://dx.doi. org/10.1177/1086026615599806

STORM, S. 2009. Capitalism and Climate Change: Can the Invisible Hand Adjust the Natural Thermostat? In Development and Change, vol. 40, 2009, pp. 1011-1038.

TEECE, D. 2010. Business models, business strategy and innovation. In Long Range Planning, vol. 43, 2010, pp. 172-194. http://dx.doi.org/10.1016/j.lrp.2009.07.003

WAGNER, M. 2007. Integration of Environmental Management with Other Managerial Functions of the Firm: Empirical Effects on Drivers of Economic Performance. In Long Range Planning, vol. 40, 2007, no. 6, pp. 611-628. http://dx.doi.org/10.1016/j. Irp.2007.08.001

\section{Contact address}

Csaba Fogarassy, associate professor, Climate Change Economics Research Centre, Szent István University, Faculty of Economics and Social Sciences, H-2100 Gödöllö, Páter Károly street 1, e-mail: fogarassy.csaba@gtk.szie.hu 